\title{
Leaf litter amendment in forest soil and their effect on the yield quality of red amaranth
}

\author{
U. K. Sarkar ${ }^{1}$, B. K. Saha ${ }^{1}$, C. Goswami ${ }^{2}$ and M. A. H. Chowdhury ${ }^{1}$ \\ ${ }^{1}$ Department of Agricultural Chemistry, ${ }^{2}$ Department of Biochemistry, Bangladesh Agricultural University, \\ Mymensingh-2202, Bangladesh
}

\begin{abstract}
A pot experiment was conducted at the open net house of the Department of Agricultural Chemistry, Bangladesh Agricultural University, Mymensingh, during the period from March to June 2007 using soil collected from the surrounding areas of Gazni sal forest of Jhenaigati upazilla under Sherpur district to study the effect of different forest tree leaf litters on growth, yield, nutrient contents of red amaranth cv. Altapety. Plant height, number of leaves plant ${ }^{-1}$, dry weight plant ${ }^{-1}$ and moisture content $(\%)$ were significantly influenced by the addition of different forest tree leaf litters and highest values were obtained from the chemical fertilizer treatment which was identical with teak leaf litter in most of the parameters. The lowest values of most of the parameters were obtained from control treatment. Nutrient contents of red amaranth were significantly influenced by the addition of different leaf litters except Mg. The highest and lowest values of most of the nutrient contents and their uptake were recorded from chemical fertilizer and control treatment, respectively. It was also observed that addition of different leaf litters substantially decreased soil acidity and significantly increased the organic matter, total $\mathrm{N}$, available $\mathrm{P}$, exchangeable $\mathrm{K}$, available $\mathrm{Ca}$, $\mathrm{Mg}$ contents in the post harvest soil. The performance of these leaf litters with respect to growth, yield, nutrient contents and their uptake by red amaranth and the soil fertility was in the order teak >eucalyptus>acacia>sal. Overall results suggested that leaf litters can be used as an alternative of chemical fertilizer in the surrounding areas of Gazni sal forest for profitable production of leafy vegetables like red amaranth.
\end{abstract}

Keywords: Leaf litter, Red amaranth, Forest soil, Yield quality

\section{Introduction}

Decomposition of leaf litter is an integral and significant part of biochemical (i.e., intrasystem) nutrient cycling and food webs of floodplain forests. Decomposition refers to both the physical and chemical breakdown of litter and the mineralization of nutrients (Boulton and Boon, 1991). Through decomposition the nutrients within leaf litter are converted into a form available for uptake by vegetation, thereby exercising a critical control on vegetation productivity (Mitsch and Gossselink, 1993 and Groffman et al., 1996). Litter plays a fundamental role in the nutrient turnover and in the transfer of energy between plants and soil, the source of the nutrient being accumulated in the upper most layers of the soil (Singh, 1971). Sal, teak, acacia, garjan, eucalyptus, mahogoni etc. are the major tree species in tropical deciduous sal forest in Bangladesh. A lot of leaf litters, twigs are fallen on the ground of this forest soil every year which play a vital role to enrich the forest soil organic matter content and are naturally decomposed and released nutrients for forest plants. These forest tree leaf litters can be applied as an organic amendment for the production of agricultural crops in the surrounding areas of the forest. However, so far limited information is available on the decomposition and the effect of sal, teak, acacia and eucalyptus tree leaf litters on the growth, yield and quality of crops. Red amaranth (Amaranthus tricolor L.) is a member of the family Amaranthaceae. In Bengali it is know as 'lal shak'. It can be grown throughout the year and can be harvested within a very short time. The chief nutritive value of red amaranth lies in their content of $\beta$ carotene and vitamin C. In Bangladesh most of the vegetables are produced in summer and winter season, while in between these two seasons, there is a lag period when scanty of vegetables exists. Red amaranth is very popular, tasty and nutritious leafy vegetable in our country but unfortunately the production of this popular vegetable is very low according to our demand. So the production of these vegetables should be increased to meet up our increasing demand. Considering all these facts, the present study was undertaken to investigate the effect of various forest tree leaf litters and chemical fertilizer applications on the growth and yield quality, nutrient contents of red amaranth. 


\section{Materials and Methods}

An experiment was conducted with red amaranth at the open net house and the chemical analyses were done in the laboratory of the Department of Agricultural chemistry and Professor Mohammad Hossain Laboratory of Bangladesh Agricultural University, Mymensingh. The soil used in this experiment was collected from surrounding area of Gazni sal forest of Sherphur district. Acacia (Acacia auriculiformis), eucalyptus (Eucalyptus camaldulensis), teak (Tectona grandis), and sal (Shorea robusta) litters were collected from fifteen different locations of Gazni sal forest. The litters were dried under open sunlight and ground in a steel grinding mill containing a fine sieve. Prepared samples were stored in desiccators before using. The experiment was carried out in Completely Randomized Design (CRD) with three replications. The experiment comprised of six treatments including a control $\left(T_{1}=\right.$ Control (no leaf litter i.e. soil only), $T_{2}=$ Acacia, $T_{3}=$ Eucalyptus, $T_{4}=$ Teak, $T_{5}=S a l, T_{6}=$ Chemical fertilizer). All the leaf litters were applied @ $20 \mathrm{t} \mathrm{ha}^{-1}$ (Chowdhury, A.H.M.R.H., 2007) and chemical fertilizers were applied @ recommended dose of fertilizer recommendation guide (BARC 2005). The seeds of red amaranth cv. Altapety were collected from the Bangladesh Agricultural Development Corporation (BADC), Mymensingh and $\left(12 \times 12\right.$ inch $\left.^{2}\right)$ earthen pots were prepared by mixing the soil with leaf litters and watered. After 1 month 30 seeds of red amaranth were sown uniformly in each pot. The chemical fertilizers were mixed with soil in the previous day of sowing. The urea fertilizer was applied at two installments. Two times thinning was done at 7 days interval and finally 10 plants of red amaranth were kept in each pot. Irrigation and other intercultural operations were done if and when necessary. The plants were harvested 40 days after sowing. Plant heights, number of leaves plant $^{-1}$, dry weight plant ${ }^{-1}$ and moisture content were measured. $\mathrm{N}, \mathrm{P}, \mathrm{K}, \mathrm{Mg}, \mathrm{Ca}, \mathrm{S}$ and Fe content of the plant samples were estimated. The $\mathrm{pH}$, organic carbon, organic matter, total nitrogen, available $\mathrm{P}, \mathrm{Ca}, \mathrm{Mg}$ and exchangeable $\mathrm{K}$ content of soils were measured. The nutrient contents of plant and soil samples were analyzed by following standard methods as outlined by Page, et. al (1982). Soil texture was determined following hydrometer method as described by Black (1965). Soil pH was measured using a glass electrode pH meter (WTW pH 522) at a soil-water ratio of 1: 2.5 as described by Ghosh et al. (1983). Soil organic C was determined by Walkley and Black's wet oxidation method as described by Jackson (1973). The data were analyzed statistically by F-test (Gomez and Gomez, 1984). The mean comparisons of the treatments were evaluated by LSD Test. Analysis of variance was done following the Completely Randomized Design (CRD) with the help of computer package MSTAT developed by Russel (1986).

\section{Results and Discussion}

\section{Plant height}

Different tree leaf litters significantly influenced the plant height of red amaranth. The highest $(30.60 \mathrm{~cm})$ and lowest $(8.00 \mathrm{~cm})$ plant height were recorded from chemical fertilizer and the control treatments, respectively. Whereas acacia, eucalyptus, teak and sal litters treated plants showed plant height as 20.33, 8.50, 18.33 and $16.07 \mathrm{~cm}$, respectively (Table 1). The results show that among the leaf litters of different trees, acacia litter was superior to other litters for producing taller plants.

\section{Number of leaves plant ${ }^{-1}$}

The effect of different tree leaf litters on the number of leaves of red amaranth was significant. The maximum (14.00) and the minimum (7.67) number of leaves were recorded from chemical fertilizer and control treatments, respectively. Whereas acacia, eucalyptus, teak and sal showed 12.33, 9.33, 11.33 and 12.33 leaves, respectively (Table 1). The maximum number of leaves was recorded from chemical fertilizer treatment which was identical to acacia, teak and sal litters. The results show that among the leaf litters of different trees, acacia and sal leaf litters were performed better to other leaf litters for producing plants having higher number of leaves of red amaranth. 


\section{Dry weight plant ${ }^{-1}$}

Significant variation in dry weight of red amaranth was observed from the effect of different leaf litters. The highest and lowest dry weights were obtained from acacia leaf litter $(1.74 \mathrm{~g})$ and sal leaf litter $(0.86 \mathrm{~g})$ treated plants, respectively (Table 1). Chemical fertilizer treated plants were statistically identical with teak and eucalyptus litter treated plants.

Table 1. Effect of different tree leaf litters and chemical fertilizer on the growth, yield, N, P, K, Ca, $\mathrm{Mg}, \mathrm{S}$ and Fe contents of red amaranth cv. Altapety

\begin{tabular}{|l|c|c|c|c|c|c|c|c|c|c|c|}
\hline Treatment & $\begin{array}{c}\text { Plant } \\
\text { height } \\
(\mathrm{cm})\end{array}$ & $\begin{array}{c}\text { Leaves } \\
\text { plant }{ }^{-1} \\
(\mathrm{No})\end{array}$ & $\begin{array}{c}\text { Dry weight } \\
\text { plant- }{ }^{-1} \\
(\mathrm{~g})\end{array}$ & $\begin{array}{c}\text { Moisture } \\
\text { content } \\
(\%)\end{array}$ & $\begin{array}{c}\text { Nitrogen } \\
\text { content } \\
(\%)\end{array}$ & $\begin{array}{c}\text { Phosphorus } \\
\text { content (\%) }\end{array}$ & $\begin{array}{c}\text { Potassium } \\
\text { content (\%) }\end{array}$ & $\begin{array}{c}\text { Calcium } \\
\text { content } \\
(\%)\end{array}$ & $\begin{array}{c}\text { Magnesium } \\
\text { content } \\
(\%)\end{array}$ & $\begin{array}{c}\text { Sulphur } \\
\text { content } \\
(\%)\end{array}$ & $\begin{array}{c}\text { Iron } \\
\text { Content } \\
\left(\mu \mathrm{g}^{-1}\right)\end{array}$ \\
\hline Control & 8.00 & 7.67 & 0.89 & 85.69 & 0.81 & 0.32 & 0.30 & 0.62 & 0.73 & 0.18 & 3.25 \\
\hline Acacia & 20.33 & 12.33 & 1.74 & 85.75 & 0.88 & 0.42 & 0.36 & 0.70 & 0.82 & 0.22 & 9.23 \\
\hline Eucalyptus & 8.50 & 9.33 & 1.31 & 85.68 & 0.91 & 0.46 & 0.38 & 0.74 & 0.85 & 0.24 & 7.16 \\
\hline Teak & 18.33 & 11.33 & 1.56 & 85.75 & 0.94 & 0.48 & 0.43 & 0.82 & 0.91 & 0.28 & 10.39 \\
\hline Sal & 16.06 & 12.33 & 0.86 & 85.72 & 0.83 & 0.39 & 0.33 & 0.60 & 0.79 & 0.18 & 6.30 \\
\hline CF & 30.60 & 14.00 & 1.13 & 85.71 & 1.02 & 0.50 & 0.46 & 0.74 & 0.98 & 0.26 & 13.46 \\
\hline LSD (0.05) & 1.61 & 3.51 & 0.45 & 0.65 & 0.18 & 0.11 & 0.09 & 0.115 & 0.162 & 0.58 & 1.343 \\
\hline CV (\%) & 5.20 & 17.30 & 19.86 & 0.42 & 11.05 & 13.93 & 14.74 & 8.60 & 10.64 & 5.03 & 8.90 \\
\hline
\end{tabular}

\section{Moisture content}

No significant variation in moisture content of red amaranth was found due to application of different leaf litters and chemical fertilizer. The maximum moisture content in red amaranth recorded from the plant treated with acacia and teak litters $(85.75 \%)$. The minimum moisture content was recorded from the plant treated with eucalyptus leaf litters $(85.68 \%)$.

Effect of different tree leaf litters and chemical fertilizers on $\mathrm{N}, \mathrm{P}, \mathrm{K}, \mathrm{Ca}, \mathrm{Mg}, \mathrm{S}$ and Fe contents of red amaranth cv. Altapety

Nitrogen: Nitrogen content of red amaranth resulting from the effect of different leaf litters was statistically significant at $1 \%$ level of significance. The maximum and minimum $\mathrm{N}$ contents were recorded from the plant treated with chemical fertilizers $(1.02 \%)$ and control treatments $(0.81 \%)$, respectively. The results shows that $\mathrm{N}$ content in acacia, eucalyptus, teak and sal leaf litters treated plants were statistically identical with that of chemical fertilizer treated plants in respect to $\mathrm{N}$ content.

Phosphorus: It was found that $\mathrm{P}$ content of red amaranth varied from 0.32 to $0.50 \%$ due to the application of different tree leaf litters. The maximum and minimum $\mathrm{P}$ content of red amaranth were recorded from the plants treated with chemical fertilizer $(0.50 \%)$ and the plants under control treatment $(0.32 \%)$, respectively. The maximum $\mathrm{P}$ content was recorded from chemical fertilizer treated plants which was identical to acacia, eucalyptus, teak and sal litters treated plants.

Potassium: Potassium content of red amaranth significantly varied among the treatments from 0.30 to $0.46 \%$. The maximum $\mathrm{K}$ content $(0.46 \%)$ was obtained from the plants treated with chemical fertilizer. The minimum $\mathrm{K}$ content $(0.30 \%)$ was recorded from the plants under control treatment.

Calcium: Calcium content of red amaranth resulting from the effect of different leaf litters was statistically significant. The maximum $(0.74 \%) \mathrm{Ca}$ was recorded from the plants treated with chemical fertilizer and the minimum $(0.62 \%) \mathrm{Ca}$ obtained from the plants under control treatment. The results show that $\mathrm{Ca}$ content of acacia, eucalyptus and teak leaf litters and chemical fertilizer treated plants were statistically identical. 
Magnesium: $\mathrm{Mg}$ content of red amaranth ranged from 0.73 to $0.98 \%$, which was not statistically significant. The maximum and minimum $\mathrm{Mg}$ contents were obtained from the plant treated with chemical fertilizer $(0.98 \%)$ and control $(0.73 \%)$ treatments, respectively.

Sulphur: Significant variation was observed in $S$ content due to different leaf litters and fertilizer application. The maximum $(0.28 \%) S$ content was obtained from the plants treated with teak leaf litter. On the contrary, the minimum $(0.18 \%) \mathrm{S}$ content was obtained from sal leaf litter treated plants and the plants under control treatment. The results showed that $S$ content in acacia, eucalyptus and teak leaf litter treated plants were statistically identical to that chemical fertilizer treated plants.

Iron: Significant variation was observed on Fe content of red amaranth due to the application of different tree leaf litters. The amount of Fe content varied from 3.25 to $13.46 \mu \mathrm{g} \mathrm{g}^{-1}$. The maximum and minimum Fe contents were obtained from chemical fertilizer $\left(13.46 \mu \mathrm{g} \mathrm{g}^{-1}\right)$ treated plants and the plants under control treatment $\left(3.25 \mu \mathrm{g} \mathrm{g}^{-1}\right)$, respectively.

$\mathrm{N}, \mathrm{P}, \mathrm{K}, \mathrm{Ca}, \mathrm{Mg}, \mathrm{S}, \mathrm{Fe}$ contents of red amaranth showed that to get better red amaranth harvest, leaf litter may be an alternative to chemical fertilizers.

\section{Effect of different leaf litters and chemical fertilizers on the chemical properties of post harvest soil}

Soil pH: The changes of soil pH value in post harvest soil of red amaranth for application of different treatments were obtained and the results are shown in Table 2. The results showed that application of different tree leaf litters increases $\mathrm{pH}$ value in soil where the highest $\mathrm{pH}$ value (5.56) was obtained from teak leaf litter treated soil. Whereas acacia, eucalyptus and sal leaf litters treated soil showed the $\mathrm{pH}$ value as $5.14,5.27$ and 5.33 , respectively. The $\mathrm{pH}$ value of control treatment was 4.56 and chemical fertilizer treated soil was 4.56 .

Table 2. Effect of different tree leaf litters and chemical fertilizer on the chemical properties of post harvest soil of red amaranth cv. Altapety

\begin{tabular}{|l|c|c|c|c|c|c|c|}
\hline Treatment & $\mathrm{pH}$ & $\begin{array}{c}\text { Organic matter } \\
(\%)\end{array}$ & $\begin{array}{c}\text { Total N } \\
(\%)\end{array}$ & $\begin{array}{c}\text { Available P } \\
\left(\mu \mathrm{g} \mathrm{g}^{-1} \text { soil }\right)\end{array}$ & $\begin{array}{c}\text { Exchangeable K } \\
\left(\mathrm{cmol} \mathrm{kg}^{-1} \text { soil }\right)\end{array}$ & $\begin{array}{c}\text { Available Ca } \\
\left(\mu \mathrm{g} \mathrm{g}-1 \mathrm{soil}^{2}\right.\end{array}$ & $\begin{array}{c}\text { Available Mg } \\
\left(\mu \mathrm{g} \mathrm{g} \mathrm{g}^{-1} \mathrm{soil}\right)\end{array}$ \\
\hline Control & 4.56 & 1.22 & 0.01 & 6.15 & 0.19 & 39.12 & 44.69 \\
\hline Acacia & 5.14 & 2.08 & 0.06 & 8.11 & 0.41 & 56.97 & 63.12 \\
\hline Eucalyptus & 5.27 & 2.04 & 0.07 & 8.93 & 0.43 & 63.31 & 67.93 \\
\hline Teak & 5.56 & 2.53 & 0.09 & 10.87 & 0.44 & 59.87 & 70.08 \\
\hline Sal & 5.33 & 2.03 & 0.05 & 7.91 & 0.36 & 35.34 & 60.43 \\
\hline CF & 4.56 & 1.28 & 0.03 & 6.98 & 0.21 & 44.22 & 46.33 \\
\hline LSD (0.05) & 0.98 & 0.06 & 0.05 & 2.48 & 0.08 & 4.32 & 4.52 \\
\hline CV (\%) & 10.64 & 5.56 & 1.06 & 16.72 & 13.81 & 4.50 & 4.22 \\
\hline
\end{tabular}

${ }^{*} \mathrm{CF}=$ Chemical Fertilizer

Organic matter: The effect of different tree leaf litters on the organic matter content (\%) in post harvest soil of red amaranth was significant. The results showed that application of different leaf litter increased \% organic matter in soil where the highest organic matter $(2.53 \%)$ was obtained from teak leaf litter treated soil (Table 2). Whereas organic matter $2.08 \%, 2.40 \%$ and $2.03 \%$ obtained from acacia, eucalyptus and sal leaf litters treated soil, respectively as compared to control treatment $(1.22 \%)$ and chemical fertilizer treated soils $(1.28 \%)$.

Total N: Total $\mathrm{N}(\%)$ in post harvest soil of red amaranth resulting from the application of different tree leaf litters varied significantly and ranged from $0.01 \%$ to $0.09 \%$ (Table 2). The results showed that application of different leaf litters increased total $\mathrm{N}$ in soil where the highest total $\mathrm{N}(0.09 \%)$ was obtained from soil treated with teak leaf litter followed by the total $\mathrm{N}(\%)$ as $0.06,0.07$ and 0.05 obtained from acacia, eucalyptus and sal leaf litters treated soil, respectively as compared to total $\mathrm{N}$ of control soil $(0.01 \%)$ and chemical fertilizer treated soil $(0.03 \%)$. 
Available P: Available $P$ in post harvest soil of red amaranth was influenced by the application of different tree leaf litters. The results showed that application of different leaf litters increased available $P$ in soil where the highest available $P\left(10.87 \mathrm{mg} \mathrm{g}^{-1}\right)$ was obtained from soil treated with teak leaf litter followed by the available P $8.11,8.93$, and $7.91 \mathrm{\mu g} \mathrm{g}^{-1}$ obtained from acacia, eucalyptus and sal leaf litters treated soil, respectively as compared to available $P$ of control soil $\left(6.15 \mu \mathrm{g} \mathrm{g}^{-1}\right)$ and chemical fertilizer treated soils $\left(6.98 \mu \mathrm{g} \mathrm{g}^{-1}\right)$.

Exchangeable K: Exchangeable $\mathrm{K}$ in post harvest soil of red amaranth varied from 0.18 to $0.45 \mathrm{cmol} \mathrm{kg}^{-1}$ soil. The results showed that application of different leaf litters increased exchangeable $\mathrm{K}$ in soil where the highest exchangeable $\mathrm{K}\left(0.44 \mathrm{cmol} \mathrm{kg}^{-1}\right)$ was obtained from soil treated with teak leaf litter followed by the exchangeable $\mathrm{K} 0.41,0.43$, and $0.36 \mathrm{cmol} \mathrm{kg}^{-1}$ obtained from acacia, eucalyptus and sal leaf litters treated soil, respectively as compared to exchangeable $\mathrm{K}$ of control soil $\left(0.19 \mathrm{cmol} \mathrm{kg}^{-1}\right)$ and chemical fertilizer treated soils $\left(0.21 \mathrm{cmol} \mathrm{kg}^{-1}\right)$.

Available Ca: The effect of different tree leaf litters on available $\mathrm{Ca}$ in post harvest soil of red amaranth was significant and varied from 38.42 to $66.19 \mathrm{\mu g} \mathrm{g}^{-1}$ soil. The results showed that application of different leaf litters increased available $\mathrm{Ca}$ in soil where the highest available $\mathrm{Ca}\left(63.31 \mathrm{\mu g} \mathrm{g}^{-1}\right)$ was obtained from soil treated with teak leaf litter followed by the available Ca $\left(56.97,59.87\right.$, and $\left.53.34 \mu^{-1} \mathrm{~g} \mathrm{~g}^{-1}\right)$ obtained from acacia, teak and sal leaf litters treated soil, respectively as compared to available Ca of control soil $\left(39.12 \mu \mathrm{g} \mathrm{g}^{-1}\right)$ and chemical fertilizer treated soils $\left(44.22 \mu \mathrm{g} \mathrm{g}^{-1}\right)$.

Available Mg: The application of different tree leaf litter increased available $\mathrm{Mg}$ in soil where the highest available $\mathrm{Mg}\left(70.08 \mathrm{\mu g} \mathrm{g}^{-1}\right)$ was obtained from teak leaf litter treated soil. Acacia, eucalyptus and sal leaf litter treated soil showed the available $\mathrm{Mg}$ content of $63.12,67.93$ and $60.43 \mathrm{\mu g} \mathrm{g}^{-1}$, respectively. The available $\mathrm{Mg}$ of control treatment and chemical fertilizers treated soil were 44.69 and $46.33 \mu \mathrm{g} \mathrm{g}^{-1}$, respectively.

The results indicate that leaf litters performed better to chemical fertilizer by improving soil quality through increasing soil $\mathrm{pH}$, organic matter, total $\mathrm{N}$, available $\mathrm{P}$, exchangeable $\mathrm{K}$, available $\mathrm{Ca}$, and available $\mathrm{Mg}$ contents of the experimental soils.

From the above discussion, it is clear that leaf litters showed its significant positive effect on yield and yield contributing characters, nutrient content and uptake by red amaranth. Utilization of leaf litters directly or indirectly would help us to increase soil organic matter. Unfortunately very little attention has been paid on our forest and the fertility of soil. Within the limit of this experiment, it can be concluded that for profitable and quality crop production and for improving soil properties, the application of leaf litters would be better than chemical fertilizers.

\section{References}

Black, C.A. 1965. Methods of soil analysis part I and part II. American Society of Agronomy. Inc. Pub. Madison. Wisconsin, USA.

Boulton, A.J. and Boon, P.I. 1991. A review of methodology used to measure leaf litter decomposition in lotic environments: Time to turn over an old leaf. Australian J. Marine Freshwater Resour. 42: 1-43.

Chowdhury, A.H.M.R.H. 2007. Effects of tree leaf litters on growth yield and nutrient uptake by red amaranth in forest soil, MS thesis, Dept. of Agroforestry, BAU, Mymensingh.

Ghosh, A.B., Bajaj, J.C., Hassan, R. and Singh, D. 1983. Soil and Water Testing Methods-Laboratory manual, Div. of soil Science and Agricultural Chemistry. IARI, New Delhi, India. pp. 221-226.

Gomez, K.A. and Gomez, A.K. 1984. Statistical Procedure for Agricultural Research. ( ${ }^{\text {nd }}$ edn.). John Wiely and Sons. New York. pp. 207-215.

Jackson, M.L. 1973. Soil Chemical Analysis, Constable and Co. Ltd. Prentice Hall of India Pvt. Ltd. New Delhi. pp. 10-114.

Mitch, W.J. and Gosselink, J.G. 1993. Wetlands 2nd ed. Van. Nosirand Reinhold, New York. pp. 205-240. 
Page, A.L., Miller, R.H. and Kuny, D.R. 1989. Methods of Soil Analysis. Part 2, 2nd edn., American Soc. Agron., Madison, Wisconsin, USA. pp. 403-430.

Russel, D.F. 1986. M-STAT Director. Crop and Soil Science Department, Michigan State University, USA.

Singh, K.P., Singh, P.K. and Tripathi, S.K. 2004. Litter decomposition and nutrient release patterns in four native tree species raised on coal mine spoil at Singrauli. Indian Biol., Ferti. Soils. 29(4): 371-378.

Singh, K.P. 1971. Litter production and nutrient turnover in deciduous forest of Varanasi Adv. Trop. Ecol. 47: 643-697.

Tantos, V. and Papionnou, A. 2000. Effect of forest species on the accumulation and distribution of organic matter and nutrients in the forest floor. Asike 175; Ereuna. Nea Seira. 13: 43-50.

Tindal, H.D. 1983. Vegetables in the Tropics. Macmillan Education Ltd. London. pp. 98-100. 